\title{
CHITOSAN DAN APLIKASI KLINISNYA SEBAGAI BIOMATERIAL
}

\author{
Bambang Irawan \\ Departemen Ilmu Material Kedokteran Gigi Fakultas Kedokteran Gigi Universitas Indonesia
}

Bambang Irawan. Chitosan dan aplikasi klinisnya sebagai biomaterial. Indonesian Journal of Dentistry 2005; 12 (3):146-151.

\begin{abstract}
The development of new materials with both organic and inorganic structures is of great interest to obtain special material properties. Chitosan [2-amino-2-deoxy-D-glucan] can be obtained by N-deacetylation of chitin. Chitin is the second most abundant biopolymer in nature and the supporting material of crustaceans, insects, fungi etc. Chitosan is a unique polysaccharide and has been widely used in various biomedical application due to its biocompatibility, low toxicity, biodegradability, non-immunogenic and noncarcinogenic character. In the past few years, chitosan and some of its modifications have been reported for use in biomedical applications such as artificial skin, wound dressing, anticoagulant, suture, drug delivery, vaccine carrier and dietary fibers. Recently, the use of chitosan and its derivatives has received much attention as temporary scaffolding to promotie mineralization or stimulate endochondral ossification. This article aims to give a broad overview of chitosan and its clinical applications as biomaterial.
\end{abstract}

Keywords : chitosan, clinical applications, biomaterial.

\section{Pendahuluan}

Dalam beberapa tahun terakhir, banyak dibicarakan suatu biomaterial dengan berbagai keistimewaan yang dipunyai dikembangkan untuk berbagai aplikasi klinis. Chitosan merupakan salah satu biomaterial yang akhir-akhir ini terus dikembangkan untuk berbagai keperluan aplikasi klinis. Sebenarnya chitosan sudah dikenal lama sebagai biokomposit suatu hidrokoloidal yang banyak terdapat di alam. Pengembangan biomaterial baru dengan menggabungkan struktur organik dan anorganik akan menghasilkan berbagai kelebihan dengan sifat-sifat yang khas dan proses sol-gel akan memberi peluang dihasilkan material baru. ${ }^{1,2}$ Chitosan dengan rumus kimia [2-amino-2-deoxy- $D$ glucan] adalah suatu polisakarida derivat chitin yang cukup luas penggunaannya pada aplikasi biomedik. Sebanyak 10 giga ton $\left(10^{13} \mathrm{~kg}\right)$ per tahun chitin dibentuk dan hancur terbuang percuma di alam. Chitin 2-acetamido-2 deoxy - $\beta$-D- Glucan secara luas ada pada binatang bertulang belakang. Chitin adalah suatu biopolimer nomor dua yang banyak terdapat di alam dan merupakan material pendukung dari binatang crustasea (binatang air berkulit keras seperti udang, kepiting, dan lain-lain), jenis serangga(insect) dan jamur (fungi). ${ }^{1,2,3}$ 
Chitosan dapat dihasilkan dari proses $\mathrm{N}$ deacetilasi dari chitin dan biasanya proses deacetilasi tidak komplit terjadi sehingga chitosan dapat dalam bentuk ko polimer 2 -amino-2 deoxy- $D$ glcopyranosa (GlcN) dan 2-acetamide-2 deoxy-Dglucopyranosa (GlcNAc). ${ }^{3}$ Perbandingan GlcN unit dibanding struktur glucopyranosa unit dikenal sebagai derajat proses deacetylasi (DD) yang menghambat efek chitosan dalam sifat fisik dan kimianya. DD lebih dari $75 \%$ berarti ada gugus amino bebas yang dapat terjadi pelepasan pada kondisi asam. Hal ini membuat bahan larut dalam larutan asam formiat,asam asetat,asam laktat,asam citrat dan asam hidroklorat. ${ }^{3}$

Dari berbagai penelitian dilaporkan bahwa di alam chitosan bentuk polimer banyak digunakan di bidang medis karena berbagai sifat yang sangat istimewa yaitu: biokompatibiliti baik; biodegradabiliti baik ; tidak bersifat toksik dan bioaktif., ${ }^{2,3}$ Produk biodegradasi bersifat tidak toksik, tidak menyebabkan reaksi immunologi, tidak menyebabkan terjadi kanker. ${ }^{3}$

Tulisan tinjauan pustaka ini bertujuan ingin mengenalkan secara singkat mengenai inovasi pengembangan chitosan sebagai biomaterial dan telah banyak digunakan untuk berbagai aplikasi klinis. Diharapkan dapat menjadi pemikiran para dokter gigi untuk dapat melakukan rekayasa chitosan dengan bahan lain untuk berbagai keperluan di bidang Kedokteran Gigi.

\section{Berbagai aplikasi klinis dari chitosan :}

Dalam dekade terakhir secara jelas terjadi penggunaan chitosan dalam berbagai aplikasi klinis. Dari informasi berbagai hasil penelitian dan produk komersial, chitosan dapat digunakan untuk regenerasi jaringan kulit pada kasus luka bakar atau ulcer necrotic; sebagai pembalut luka (wound dressing); sebagai benang jahit untuk proses pembedahan; sebagai suatu membran barier untuk mencegah pertumbuhan kedalam dari jaringan ikat yang tidak dikehendaki. ${ }^{3}$

Di samping itu gabungan chitosan dengan bahan lain sudah digunakan sebagai penghantar obat-obatan (drug delivery system) dan sebagai pembawa vaksin (vaccine carier) secara oral. Selanjutnya chitosan digunakan sebagai scaffold untuk suatu tissue engeneering, serta dalam prosedur implantasi yang berinteraksi dengan jaringan hidup.

Akhir-akhir ini untuk suatu industri pangan telah dikembangkan program makanan berserat (dietary fibers) dari chitosan yang ditujukan bagi orang yang mengalami kelebihan berat badan.

\section{Penyembuhan luka}

Chitin dan chitosan memberi efek pada proliferasi sel fibroblast kulit manusia dan sel keratinosit secara in vitro. ${ }^{4}$ Hasil penelitiannya menunjukkan chitosan chlorida CL 313A mempunyai efek stimulasi pada proliferasi sel fibroblast yang tergantung pada derajat deacetilasi yang lebih tinggi. Kultur fibroblast dibagi 2 fenotipe yang stabil dan menunjukkan tergantung pada donor meskipun tidak ada hubungan dengan jenis kelamin, umur dan lokasi anatomis. Keadaan mitogenik distimulasi oleh CL 313 A dalam menjawab fibroblast tergantung adanya serum. Hal ini secara tidak langsung bahwa chitosan akan berinteraksi dengan komponen serum atau sebagai faktor penyembuhan luka. Efek chitosan pada keratinosit juga tergantung pada derajat deacetylasi. Chitin-50 A (37\% deacetylasi) tidak memberi efek, tetapi bila CL 313 A (89\%) dapat menghambat proses proliferasi. Hal ini menunjukkan bahwa makin tinggi derajat deacetylasi chitosan akan memberi keaktifan yang lebih besar secara biologis bila dibandingkan chitin . Selanjutnya chitosan kemungkinan mempunyai potensi sebagai agen penyembuh luka atau bahan pembalut luka (wound dressing). ${ }^{4}$

Chitin telah digunakan dalam bentuk gel dengan cara injeksi yang diaplikasikan pada bedah jaringan periodontal. ${ }^{5}$ Hasil penelitian menunjukkan bahwa waktu penyembuhan luka 2 menit 15 detik. $^{5}$ Larutan yang digunakan dicampur dengan larutan hidroalkohol untuk terjadinya acetylasi selama 45 detik pada temperatur ruang dengan konsentrasi chitin 3,6\%. Pada konsentrasi tersebut agar terjadi sineresis yang terbatas dan meningkatkan sifat mekanis gel dan viskositasnya yang sesuai untuk dilakukan perletakan secara injeksi. ${ }^{5}$

Modifikasi chitosan dengan arginine yaitu 1 etil-3-(3-dimetil amino propil carbodimide dan $\mathrm{N}$ hidroksi succinimide sebagai bahan penyatu yang digunakan sebagai anti pembekuan darah (anti coagulation) ${ }^{6}$ Aktivitas anti pembeku darah dari aldehid glukosa yang bersilang menyatukan chitosan dan arginine, membran chitosan dievaluasi dengan waktu prothrombin, waktu thrombin dan waktu aktivasi sebagian thromboplastin. ${ }^{6}$ Hasil penelitiannya menunjuk-kan konjugasi chitosan dan arginine menyebab-kan waktu aktivasi sebagian thromboplastin menjadi lebih panjang 2 kali bila dibandingkan hanya dengan chitosan. ${ }^{6}$ Hal tersebut diusulkan bahwa konjugasi chitosan dan arginine dapat digunakan sebagai biomaterial untuk anti pembekuan darah (anti coagulation).

Gabungan chitosan dan alginat yang digunakan sebagai pembalut luka (wound dressing). ${ }^{7}$ Penelitian 
menggunakan kalsium alginat sebagai pembalut luka secara bermakna meningkatkan penyembuhan kulit yang dicangkokkan. Chitosan dikenal dapat digunakan dalam penanganan luka dengan sifat hemostatik. Gabungan chitosan-alginat membentuk kompleks membrane polielektrolit yang akan mempercepat penyembuhan luka terpotong pada binatang percobaan bila dibandingkan pembalut luka konvensional. ${ }^{7}$ Kombinasi alginat-chitosan secara klinis telah dapat menyembuhkan ulcer kronis dan saat ini telah dipasarkan secara komersial. ${ }^{7}$

\section{Petunjuk terjadi regenerasi tulang}

Semen apatite yang dicampur dengan chitosan telah digunakan pada percobaan implantasi pada tulang tibia tikus ${ }^{8}$ Penelitian membandingkan semen anti-washout apatit dan chitosan dengan semen apatit konvensional yang di implantasi pada kerusakan jaringan tulang tibia tikus dan diamati selama 16 minggu. Pada 2 minggu pertama ada respons jaringan pada jaringan lunak. Pada kelompok semen apatit terlihat respons inflamasi sedang, terdapat partikel kecil dari semen apatit disekitar jaringan kulit dan banyak sel giant di sekitar partikel semen. Sedangkan pada kelompok semen apatit-chitosan hanya terjadi respons inflamasi ringan dan sedikit sel giant. ${ }^{8}$ Hasil penelitian menunjukkan bahwa tidak ada perbedaan bermakna antara kelompok semen apatit-chitosan dan semen apatit saja dengan respons jaringan tulang. Tidak ada percepatan atau hambatan proses osteokonduktiviti dengan penambahan chitosan untuk terbentuknya tulang baru. ${ }^{8}$

Gabungan chitosan dengan derajat dea-cetilasi (DD) $85 \%$ dan protein dari hasil isolasi kacang kedele (soy bean) akan membentuk membran dengan ketebalan 45-64 $\mu \mathrm{m} .{ }^{9}$ Kombinasi kedua bahan ini menghasilkan membran dengan struktur biphasik yang secara in situ berbentuk porus melalui 2 tahap mekanisme degradasi. Dalam penelitian ini di evaluasi efek penggunaan radiasi sinar $\beta$ eta untuk mensterilkan dalam hal sifat-sifat yang dimiliki membran gabungan chitosan dan protein isolasi dari kacang kedele yang digunakan sebagai petunjuk terjadi regenerasi tulang. ${ }^{9}$ Hasil penelitian menunjukkan secara umum tidak ada perubahan substansi yang terdeteksi pada sifat yang dimiliki kecuali energi permukaan yang sedikit lebih tinggi. ${ }^{9}$

Chitosan dengan struktur makroporus yang diperkuat dengan bubuk kalsium fosfat seperti hidroksi apatit atau kalsium fosfat dengan menggunakan glass melalui teknik separasi dengan panas digunakan sebagai scaffold. ${ }^{10}$ Penelitian menggunakan osteoblast manusia seperti MG 63 cell untuk kultur komposit scaffold sampai dengan 11 hari kemudian dianalisa pertumbuhan sel dan hidroksi apatit yang dikombinasi dengan glass bila dibandingkan scaffold chitosan-hidroksi apatit tanpa glass. ${ }^{10}$ Hasil lain penelitian ini menunjukkan bahwa penggabungan glass dalam matriks chitosan akan mempercepat pertumbuhan sel, aktivitas alkaline phosphatase dan produksi osteocalcin bila dibandingkan dengan menggunakan hidroksi apatit saja. ${ }^{10}$

\section{Material pengganti tulang}

Pengabungan fosfor dengan chitosan dan penambahan semen kalsium fosfat telah diteliti karakteristiknya oleh Wang dkk. ${ }^{11}$ Bahan yang digunakan merupakan gabungan chitosan dengan fosfor menggunakan $\mathrm{P}_{2} \mathrm{O}_{5}$ dalam asam methane sulfonat dan merupakan produk penggabungan fosfor dengan chitosan yang larut dalam air. Semen kalsium fosfat yang digunakan 2 macam yaitu mono calcium phosphat monohidrat dan kalsium oksida dalam larutan buffer $1 \mathrm{M}$ fosfat $(\mathrm{pH}=7,4)$ dan dicalcium phosphat dihidrat dan kalsium hidroksida dalam larutan $1 \mathrm{M} \mathrm{Na}_{2} \mathrm{HPO}_{4}$ yang digunakan untuk meningkatkan sifat mekanis dengan penambahan Pchitosan yang larut dalam air. Hasil penelitian menunjukkan bahwa kekuatan kompresi dan modulus Young pada kedua macam semen kalsium fosfat setelah proses pengerasan akan terjadi peningkatan dan waktu pengerasan sedikit lebih panjang (15 menit) bila ditambahkan P-chitosan yang larut dalam air pada cairan semen. ${ }^{11}$ Hasil yang didapat dari penelitian ini adalah semen kalsium fosfat dengan penambahan P-chitosan akan memberikan karakteristik yang baik untuk aplikasi klinik.

Semen kalsium fosfat dengan chitosan dan asam sitrat sebagai material pengganti tulang. ${ }^{12}$ Semen kalsium fosfat yang digunakan di proses sehingga setelah dicampur mempunyai bentuk dengan konsistensi seperti permen karet (chewing gum). Komponen bubuk semen terdiri atas $\alpha-$ tricalcium phosphat dan tetracalcium phosphat yang dibuat dengan cara dekomposisi keramik hidroksi apatit bentuk blok(kubus). Cairan semen terdiri atas larutan asam sitrat,chitosan dan glukosa. Dalam penelitian ini menggunakan $20 \%$ asam sitrat (grup 20) dan $45 \%$ asam sitrat(grup 45). Hasil yang didapat adalah waktu pengerasan semen $=5,5$ menit untuk grup 20 dan 6,4 menit pada grup $45 .{ }^{12}$ Setelah 3 dan 6 minggu maka kekuatan kompresi adalah $15,6 \mathrm{MPa}$ (grup 45) dan 20,7 MPa(grup 20). ${ }^{12}$ Reaksi inflamasi pada sekitar semen yang diletakkan pada 
tulang dan jaringan subcutan pada tikus percobaan lebih menonjol pada grup 45 bila dibandingkan dengan grup 20 pada 1 minggu pembedahan. ${ }^{12}$ Setelah 4 minggu reaksi inflamasi menghilang dari semen yang mengelilingi tulang pada kedua grup percobaan.

\section{Sistim penghantar obat( Drug delivery system)}

Chitosan digabungkan dengan semen apatite anti-washout dan dimasukkan obat antibiotik telah diteliti secara in vitro dan antibiotik dapat dilepaskan secara berkala. ${ }^{13}$. Bahan antibiotik yang digunakan yaitu sodium flomoxef sebesar $10 \%$ yang dimasukkan dalam bubuk semen apatit-chitosan. Waktu pengerasan bahan semen tergantung dari jumlah kadar sodium flomoxef. Jumlah sodium flomoxef sebesar $2 \%$ akan memberi waktu pengerasan 5,7 menit sedangkan $10 \%$ sodium flomoxef akan memperpanjang waktu pengerasan menjadi 6,3 menit. $^{13}$ Antibiotik sodium flomoxef yang dilepaskan dievaluasi dengan cara masa semen apatit-chitosan yang telah mengeras dan direndam dalam larutan saline kemudian diperiksa sodium flomoxef yang dilepaskan dengan $U V$ Spectrophotometer secara berkala. Dengan analisa $X$-ray diffraksi menun-jukkan bahwa formasi hidroksi apatit dari semen apatit-chitosan akan mengalami pengurangan setelah 24 jam dimana kadar sodium flomoxef menjadi $8 \%$. Sodium flomoxef yang dilepaskan dari semen apatit-chitosan memperlihatkan profil yang khas dan diamati pada sistem penghantaran obat $(\mathrm{DDS}=d r u g$ delivery system) pada tulang belakang. ${ }^{13}$ Perubahan konsentrasi chitosan dapat mengontrol jumlah obat yang akan dilepaskan dari bahan semen apatitchitosan. Selanjutnya dapat dianjurkan bahwa penggunaan semen apatit-chitosan dapat berpotensi baik sebagai sistem penghantaran obat yang digunakan pada operasi pembedahan. ${ }^{13}$

Chitosan dan asam poliakrilat dengan polimer sebagai mucoadhesive dapat menghantar-kan obat secara transmukosa ( Transmucosal drug delivery $=$ TMD) telah diteliti secara in vitro. ${ }^{14}$ Bahan obat yang digunakan yaitu Triamcinolone acetonide diletakkan dalam kompleks polimer chitosan-asam poliakrilat berupa lapisan film tipis. Triamcinolone acetonide tersebar rata pada polimer berupa film suatu kompleks chitosan dan asam poliakrilat tanpa terjadi interaksi dengan kompleks polimer. Kemampuan pelepasan triamcinolone acetonide dari polimer mucoadhesif bentuk film tergantung pada waktu, $\mathrm{pH}$, besarnya beban obat yang terkandung dan perbandingan chitosan/asam poliakrilat. ${ }^{14}$ Jadi perbandingan chitosan/asam poliakrilat dalam kompleks polimer berupa film dapat digunakan mengontrol pelepasan triamcinolone acetonide dan sistem penghantaran secara transmukosa. ${ }^{14}$

\section{Vaksinasi secara oral}

Chitosan dalam bentuk mikropartikel telah diteliti dan digunakan untuk vaksinasi secara oral. ${ }^{15}$ Mikropartikel chitosan yang digunakan 4,3 $\pm 0,7 \mu \mathrm{m}$ dan zeta potensial muatan positif $20 \pm 1 \mathrm{mV}$. Ukuran partikel yang lebih kecil dari $10 \mu \mathrm{m}$ dapat diambil oleh sel M dari Peyer's patches sehingga mikropartikel cocok digunakan untuk sistem vaksinasi. Dengan pemeriksaan confocal laser scanning microscope(CLSM) menunjukkan bahwa model antigen ovalbumin akan terjebak diantara mikropartikel chitosan dan tidak hanya berhubungan dengan permukaan luarnya. Hasil penelitian diverifikasi dengan menggunakan field emission scanning electron microsope yang menunjukkan bahwa struktur porus dan mikropartikel chitosan dengan model kompon ovalbumin menghasilkan kapasitas muatan sekitar $40 \% .^{15}$ Kira-kira 90\% ovalbumin akan tinggal di mikropartikel chitosan setelah dilepaskan selama 4 jam dalam larutan buffer saline fosfat dengan $\mathrm{pH}=7,3$. Dapat disimpulkan bahwa mikropartikel chitosan menunjukkan sifat yang sesuai baik secara in vitro maupun in vivo untuk vaksinasi secara oral. ${ }^{15}$

\section{Sifat biodegradasi baik dan sitotoksisitas rendah}

Gabungan bubuk $\beta$-dicalcium pirophosphat dan glukosa sebagai mediasi membran chitosanpolietilen glikol telah diteliti sifat biodegradasi dan sitotoksisitasnya. ${ }^{16}$ Sifat sititoksisitas dari glukosa $\beta$-dicalcium pirophosphat dilakukan kultur sel fibroblast dengan menggunakan metode NIH 313. Ekstrak yang dihasilkan dari perendaman glukosa- $\beta$ dicalcium pirophosphat (G- $\beta$-DCP) pada larutan buffer berisi lysozyme untuk selama 2,7,14,21 dan 28 hari. Substansi yang dilepaskan G- $\beta$-DCP akan dianalisa dengan Gas -chromatography-mass spectrometry dan Inductively coupled plasma atomic emission spectrometry. Perubahan secara morfologi, komposisi kimia dan struktur kristal dipelajari dengan menggunakan scanning electron microscope dan $X$-ray diffration. Hasil penelitian yang didapat ekstrak dari kultur dengan sel fibroblast yang tumbuh akan meningkat apabila ekstrak berasal dari $\beta$-dicalciumpirophosphat yang memberi tambahan berat pada komposit G- $\beta$-DCP setelah direndam selama 7 hari. $^{16}$ Selanjutnya dengan semakin lama waktu perendaman maka jumlah sel akan meningkat. Hal ini didapat bahwa glukosa amine dan kalsium 
secara bertahap akan dilepaskan dari komposit G- $\beta$ DCP yang berhubungan dengan nutrisi untuk pertumbuhan sel fibroblast. Pelepasan ion kalsium dan konsentrasi glucosa amine dapat diatur dengan pemberian $\beta$-DCP. Sifat degradasi dari komposit G$\beta-\mathrm{DCP}$ mirip dengan cara " onion degradation model" dengan G- $\beta$-DCP akan mengalami degradasi dari lapisan luar ke lapisan dalam.16. Dengan perkembangan material maka dapat berpotensi besar sebagai substrat sel pada perkembangan tissue engineering. ${ }^{16}$

Chitosan dalam bentuk hidrogel digabung-kan pati (starch) diteliti sebagai bahan bio-degradebel dengan cara mereduksi alkilasi reaksi silang. ${ }^{17}$ Pati adalah biopolimer dari hasil pertanian yang bersifat biodegradebel, akan meningkatkan kemampuan biodegradebel chitosan dan harganya relatif murah. Bahan pati-chitosan bentuk hidrogel diproduksi dengan cara oksidasi bahan pati yang larut dan menghasilkan polialdehid kemudian terjadi reaksi silang dengan chitosan melalui pengurangan reaksi alkilasi. Pembesaran perbandingan membran patichitosan akan meningkat secara bertahap dengan meningkatnya pati, tetapi hal itu selalu lebih rendah bila dibandingkan chitosan alam. Dalam keadaan kering membran pati-chitosan dengan perbandingan pati rendah $(0,16 ; 0,38)$ memper-lihatkan nilai kekuatan tarik yang mirip dengan nilai chitosan alam dimana nilainya akan turun dengan meningkatnya jumlah pati $(0,73-1,38)$. Membran pati-chitosan dalam larutan buffer fisiologis akan memberi kekuatan tarik antar 2,8 dan 1,0 MPa. Nilainya akan turun sesuai dengan meningkatnya perbandingan pati $(0,16-1,36)$. Bila membran diletakkan dalam larutan buffer fisiologis saja maka kehilangan berat yang sedang akan terdeteksi untuk 2 minggu pertama. ${ }^{17}$ Berat yang tinggal dari perbandingan membran pati yang rendah $(0-0,38)$ mendekati $85 \%$ sementara pada ratio tinggi $(0,73-1,55)$ akan dipertahankan sekitar $70 \%$ setelah 3 bulan. ${ }^{17}$ Bila membran diletakkan pada larutan $\alpha$-amilase maka akan terjadi kehilangan berat yang sangat cepat. Untuk ratio membran pati rendah $(0,16 ; 0,38 ; 0,73)$ sisa berat yang diukur menjadi $11 \% ; 6 \% ; 20 \%$ sedangkan untuk ratio membran tinggi $(1,04$ dan 1,36) akan terjadi pengurangan berat menjadi $45 \%$ dan $30 \%$ setelah 2 bulan diletakkan dalam enzim. ${ }^{17}$ Analisa dengan scanning electron microscope menunjukkan degradasi membran akibat enzim $\alpha$ amilase menujukkan permukaan yang kasar. ${ }^{17}$

\section{Pembahasan}

Aplikasi klinis chitosan untuk penyembuhan luka ada beberapa penelitian yang meng-gabungkan chitosan dengan bahan lain dalam hal agen penyembuhan luka, penggunaan secara injeksi setelah perawatan periodontal, kemampuan anti pembekuan darah dan sebagai bahan pembalut luka. Chitosan - chlorida digunakan untuk menstimulasi proliferasi sel fibroblast dan penghambatan sel keratinosit sebagai agen penyembuhan luka. Chitosan dalam larutan hidroalkohol berbentuk gel yang penggunaanya secara injeksi digunakan untuk penyembuhan luka setelah operasi penyakit periodontal seperti periodontal pocket, infra bone defect dan lain lain. Gabungan chitosan -arginine akan memberi efek waktu pembekuan darah menjadi lebih lama sehingga bahan ini berpotensi sebagai biomaterial dengan kemampuan anti coagulant. Biasanya pembalut luka melekat pada permukaan luka akan menyebabkan lamanya proses penyembuhan. Pasien akan merasa sakit karena berkali-kali dilepaskan pembalut luka. Penggunaan chitosan dan sodium alginat dalam bentuk seperti spons sebagai gel hidrofilik akan memberikan lingkungan basah yang mempercepat penyembuhan luka dan terjadi regenerasi epidermal. Kemudian modifikasi chitosan-alginate sudah digunakan secara komersil untuk pembalut luka dan mengobati luka yang kronis.

Petunjuk regenerasi tulang ada beberapa laporan penelitian seperti chitosan - semen apatite anti- washout terhadap pertumbuhan jaringan tulang hanya disertai respons inflamasi ringan dengan sedikit ditemukan sel giant. Selanjutnya gabungan chitosan dengan protein hasil isolasi kacang kedele akan memberikan membrane yang dapat digunakan untuk petunjuk regenerasi tulang. Kemudian chitosan dengan struktur makroporus diperkuat dengan semen kalsium fosfat merupakan scaffold yang digunakan untuk regenerasi tulang baru.

Beberapa penelitian menunjukkan bahwa chitosan dapat digunakan sebagai material pengganti tulang. Gabungan Phosphor-chitosan dan penambahan semen kalsium fosfat akan memberikan kekuatan kompresi dan modulus Young yang cukup sebagai material semen tulang. Disamping itu gabungan chitosan-asam citrat dan semen kalsium fosfat akan menjadikan bahan semen tulang dengan konsistensi yang baik.

Chitosan juga sudah digunakan sebagai bahan untuk menghantarkan obat. Obat antibiotik sodium flomoxef yang dimasukkan kedalam gabungan 
chitosan-semen apatite dilaporkan dapat melepaskan obat secara berkala kedalam tubuh dalam proses pengobatan. Telah dilaporkan juga gabungan chitosan-asam poliakrilat dapat menghantarkan obat triamcinolone acetonide secara transmukosa. Chitosan dalam bentuk mikropartikel telah digunakan untuk membawa vaksin yang diberikan secara oral.

Chitosan mempunyai sifat biodegradasi yang baik dan sitotoksisitas rendah. Suatu membrane terbuat dari gabungan bubuk $\beta$-dicalcium pirophosphat dan glukosa sebagai mediasi membran chitosan-polietilen glikol mempunyai sifat biodegradasi seperti onion degradation model dan sitotoksisitas rendah. Membran ini berpotensi dapat digunakan dalam perkembangan tissue engineering. Disamping itu gabungan chitosan-starch akan meningkatkan kemampuan biodegradasi dan berbiaya lebih ekonomis.

Dari berbagai uraian mengenai kegunaan chitosan dalam berbagai aplikasi klinis sebagai biomaterial maka dapat disimpulkan bahwa chitosan suatu polisakarida yang banyak terdapat di alam memiliki berbagai sifat istimewa. Sifat istimewa yang dimiliki antara lain biokom-patibiliti baik, biodegradebel, tidak bersifat toksik, tidak menyebabkan terjadi reaksi immunologi, tidak menyebabkan kanker. Dengan keisti-mewaan yang dimiliki maka chitosan dan modifikasi dengan bahan lain dapat digunakan untuk aplikasi klinis sebagai biomaterial.

\section{Daftar pustaka}

1. Terbojevich M. Chitosan Dalam Handbook of Hydro colloids, Phillips GO dan William PA (ed) $1^{\text {st }}$ ed. Woodhead Publishing Ltd. 2000; p. 367-78.

2. Zhu AP, Zhang Z, Shen J. Preparation and characterization of novel silica- butyrylchitosan hybrid biomaterials. J Mater Sci: Mater Med 2003; 14: 27-31.

3. Silva RM, Silva GA, Coutinho OP, Mano JF, Reis RL. Preparation and characterization in simulated body conditions of glutaraldehyde cross linked chitosan membranes. J Mater Sci : Mater Med 2004; 15: 1105-12.

4. Howling GI, Dettmar PW, Goddard PA, Hampson FC, Dornish M, Wood EJ, The effect of chitin and chitosan on proliferation of human skin fibroblasts and keratinocytes in vitro. Biomaterials 2001; 22: 2959-66.
5. Gerentes P, Vachoud L, Doury J, Domard A. Study of a chitin-based gel as injectable material in periodontal surgery. Biomaterials 2002; 23 : 1295 1302.

6. Liu WG, Zhang JR, Cao ZQ, Xu FY, Yao KD. A chitosan- arginine conjugate as a novel anticoagulation biomaterial. J Mater Sci : Mater Med 2004; 15: 1199-1203.

7. Paul W, Sharma CP. Chitosan and alginate wound dressings : A short review. Trends Biomater Artif Organs 2004; 18: 18-23.

8. Takechi M, Ishikawa K, Miyamoto $\mathrm{Y}$, Nagayama M, Suzuki K. Tissue responses to anti-wasout apatite cement using chitosan when implated in rat tibia. $J$ Mater Sci: Mater Med 2001; 12: 597-602.

9. Silva RM, Elvira C, Mano JF, San Roman J, Reis $\mathrm{RL}$. Influence of $\beta$ - radiation sterilisation in properties of new chitosan/soybean protein isolate membranes for guided bone regeneration. $J$ Mater Sci : Mat Med 2004;15: 523-28.

10. Zhang Y, Zhang M. Cell growth and function on calcium phosphate reinforced chitosan scaffolds. $J$ Mater Sci : Mat Med 2004; 15: 255-60.

11. Wang XH, Ma JB, Wang YN, He BL. Structural characterization of phosphorylated chitosan and their application as effective additives of calcium phosphate cements. Biomaterials 2001; 22: 2247-55.

12. Yokoyama A, Yamamoto S, Kawasaki T, Kohgo T, Nakasu M. Development of calcium phosphate cement using chitosan and citric acid for bone substitute materials. Biomaterials 2002; 23: 1091101.

13. Takechi M, Miyamoto Y, Momota Y, Yuasa T, Tatehara S, Nagayama $M$. The in vitro antibiotic release from anti-wasout apatite cement using chitosan. J Mater Sci : Mater Med 2002; 13: 973-8.

14. Ahn JS, Choi HK, Chun MK, Ryu JM, Jung JH, Kin YU et all. Release of triamcinolone acetonide from mocoadhesive polymer composed of chitosan and poly(acrylic acid) in vitro. Biomaterials 2002; 23 : 1411-6

15. Van der Lubben IM, Verhoef JC, Van Aelst AC, Borchard G, Junginger HE. Chitosan microparticles for oral vaccination: preparation, characterization and preliminary in vivo uptake studies in murine Peyer's patches. Biomaterials 2001; 22: 687-94.

16. Wang JW, Hon MH. Biodegradation behavior and cytotoxicity of composite membrane composed of $\beta$ dicalcium pyrophosphate and glucose mediated (polyethylene glycol/chitosan). J Mater Sci: Mater Med 2004; 15: 129-36.

17. Baran ET, Mano JF, Reis RL. Starch-chitosan hydrogels prepared by reductive alkylation crosslingking. J Mater Sci: Mat Med 2004;15: 759-65. 